\title{
How to Measure Self-discipline as Good Citizen for the Undergraduates
}

\author{
Suntonrapot Damrongpanit \\ Department of Educational Foundations and Development, Faculty of Education, Chiang Mai University, Thailand
}

Copyright $\mathrm{C} 2019$ by authors, all rights reserved. Authors agree that this article remains permanently open access under the terms of the Creative Commons Attribution License 4.0 International License

\begin{abstract}
The objective of this research is to develop and examine the model validity used to measure self-discipline as good citizenship of 1,407 undergraduates, including $41.578 \%$ of males and $58.422 \%$ of females, from 18 different faculties by stratify random sampling. A tool used in this study is the questionnaire evaluating self-discipline, which is consisted of a set of 89 questions for measuring at 5 different levels and the reliability is 0.963 . Data analysis is conducted by the use of descriptive statistics and the second order factor analysis is also conducted by Mplus 7.4 program. The findings show that the measurement model used to explain self-discipline as good citizenship is at a good validity level, which includes 4 factors from a total of 20 indicators. The patience, determination, and intention factor (measured by 3 indicators) was the highest factor loading coefficient followed by responsibility ( 8 indicators), honesty (2 indicators), and self-regulation (7 indicators) factors, respectively.
\end{abstract}

Keywords Self-discipline, Citizenship, Indicators, Self-regulation, Self-control, Factors, Undergraduates

\section{Introduction}

Self-discipline is one of important fundamental qualities of each individual for self-control, awareness of responsibility and future planning, compliance with regulations, respect for differences, and value of honor . When the community is consisted of human resources possessing self-discipline, it may lead to a harmonized society and social development can be quickly accomplished. Consequently, developing self-discipline has been inculcated to children through socialization at all levels of education, especially in the childhood because it is essential for a long-term development of self-discipline [1]. In Thailand, developing self-discipline has been implemented since the children attend the primary education of which is similar to that of other countries. Not only focused on physical preparation, but also practices according to the agreements are also emphasized together with patience and dedication, especially class discipline ([2]; [3]; [4]). As the children grow up, a variety of objective discipline starts responding to the development at each stage of the students and is carried out to the educational management at a university level when the model of development for each stage is theoretically different [5]. However, the process of self-discipline development in Thailand is obviously discovered and developed in the early childhood and secondary levels exclusively.

To develop self-discipline among the undergraduates, the scope is rather wider than that for both primary and secondary students owing to the fact that the undergraduates can develop their ability to utilize their thoughts, reasons, and decision making at the same level as adults. As a result, the concept of organizing an activity is connected with society, provides the foundation of self-discipline aimed at being good citizenship of a society and the nation [6], and emphasizes on community services, honesty, and sacrifice for public interests in order to maintain the duties of a good citizen [7]. Due to a variety and complexity in the scope of self-discipline in the undergraduates as well as the lack of knowledge to indicate this scope, it is necessary to specify the essential qualities and structure of self-discipline in order to assist the associates in designing an activity or innovation to obviously develop self-discipline as good citizenship both inside and outside of the classroom.

Chiang Mai University is aware of developing self-discipline and making a preparation for the students before attending the society which is full of different conflicting viewpoints. Besides, the collective statistic information, regarding disciplinary offending behaviors of the students including causing unrest in the campus, using false documents, breaking university's regulations, damaging the university's properties etc. [8], shows that these matters are still continual and distinctly signify the lack of promoting self-discipline among the students. The researcher also found that all associates, who deal with 
student development, lack information about the scope of the students' self-discipline to be used in conducting an activity and improving types of activities that correspond to the qualities of students 'self-discipline, or diminishing the previous activities, which are irrelevant or ineffective. Therefore, the researcher and all of the associates would like to conduct a research in order to obtain the summary of measuring and indicating the qualities of self-discipline which will be a great start to reflect the scopes of responsibilities for all concerning sectors to continually develop the students effectively.

\section{Literature Reviews}

Self-discipline is not a new issue in the field of educational research, but it has been one interesting issue in the research for over fifty years, starting in around 1950 [9]. In the beginning, there were several similar terms used to mention it, which included self-control, self-management, self-directed behavior, self-discipline [1]. Later, the scholars briefly and conformingly defined that self-discipline means the qualities in an individual to accept social roles and ethics for expressing his behaviors without being compelled or awarded ([10]; [11]; [1]). It seems that self-discipline is rather an abstract issue and the behaviors representing self-discipline cannot clearly be identified due to the differences in child's ethical development mechanism at each stage [12] as well as the differences in social factors around the children ([3]; [9]; [13]; [14]). Consequently, the study on self-discipline lacks specific measurement and it reveals that some studies applied other measuring tools, such as Brief Self-Control Scale (BSCS) [15] and Social and Learning Behavior Questionnaire (SSL) [16], although some scholars mentioned the differences in descriptions and characteristics of the variable.

Self-discipline is a personal quality which can be described by the approach of moral development and it involves advanced behavioral development called "prosocial" which the behaviors include sharing, providing assistance, and facilitating for public interests [17]. When it comes to a strong intrinsic motivation to express these prosocial behaviors, it is called "altruism" and Bandura [18] explains that ethical possession is an effect of social learning when roles are as models leading to reciprocal determinism of children through "observational learning" process that they can initially learn and develop at the age of two. However, Piaget [19] explains that social development is an effect of observing and exploring reasons towards the surrounding symbols in order to significantly adjust oneself to the environment. This change appears at being born (sensorimotor stage), continues to the stage that children can utilize the reasons. This completes at the age of over 12 (concrete operational stage) when their egocentric viewpoint reduces and they start to pay more attention to other individuals' needs. The approach proposed by Kohlberg [20] explains that moral and ethical developments change according to the stages of life when rational mechanism completes at the age with an ability to learn universal moral rule, resulted from the influence of individual values all over the world [12]. As a result, the behavioral indicators of child's self-discipline are different because the stages of life, discipline-stimulating environment, and parenting or nurturing types are different ([4]; [1]) and it is likely that self-discipline cannot be clearly and equally measured if the children are in different social and cultural contexts.

Since the qualities of self-discipline are not clearly defined, some researchers start to pay attention to the measurements based on their own concepts. Mahatmaharti et al [21] studied the structure of measuring self-discipline by synthesizing the structure of measurements according to the approaches proposed by several scholars and three main groups of indicating structure of self-discipline are discovered including; 1) capability in self-regulation according to the approach of Zimmerman [22] describing that there are 7 indicators including capabilities in personal goal setting, self-control, self-direct, self-evaluation, self-motivation, self-encouragement, keeping self-promise, 2) capability in self-control according to the approach proposed by Gilliom et al [23] describing that there are 5 indicators including capabilities in emotional control, self-control under regulation, decision making, operation, situational control, and 3) capability in maintaining punctuality according to the approach proposed by Lohbeck et al [16] with 4 indicators including courage to temporary restrain from favorite or enjoyable things, to mention about success, to learn things with enthusiasm, and not to procrastinate. After analyzing these elements, the findings show that self-discipline can be measured by these three elements with 7 indicators, comprising no procrastination, capability in personal goal setting, capability in self-control, capability in self-encouragement, capability in self-evaluation, capability in keeping self-promise, and capability in decision making.

In the Thai context, the studies on self-discipline have been from synthesizing 105 pieces of research, which a half of those were conducted in early childhood and primary students. There was only $5.60 \%$ of those were conducted in the undergraduates and the definition of the term for measurement was rather narrow $.80 \%$ of those define self-discipline as self-control to follow the rules, agreements, or regulations. Moreover, there was the definition corresponding to other qualities, which was differently varied- for example, responsibility $(58.49 \%)$, honesty $(17.92 \%)$, and patience $(16.98 \%)$. Therefore, the explanation of characteristics in the indicators of self-discipline from the research is unable to be applied in a thorough explanation of self-discipline for the undergraduates in Chiang Mai University. It is necessary to re-conduct the study of the indicators and specific elements by synthesizing relevant theories and findings from previous research projects together with considering rules and regulations according to the university's 
announcements .The researcher believes that the qualities of the students that represent self-discipline as good citizenship consist of 4 main (latent) factors and require 20 indicators, which are: (A) responsibility factor (consisting of 8 indicators) which refers to capability in accomplishing tasks or assignments, class attention, class preparation and care for educational aid, participation in class and activities held by the faculty and university, punctuality, protection for university's properties, follow-up of the faculty and university's information, and self-care, (B) honesty factor (consisting of 2 indicators) which refers to ability to accept the truth and avoid cheating, (C) compliance with regulations factor )consisting of 7 indicators (which refers to respect for traffic regulations, restraint from alcohol drinking or drug use, restraints from physical and mental abuse, restraint from gambling, restraints from offenses against properties, compliance with university's rules, regulations and announcements, and restraints from possession and carrying of lethal weapons, (D) patience, determination, and intention factor (consisting of 3 indicators) which refer to an attempt to accomplish the tasks and assignments, physical and emotional self-control, and acquisition of additional knowledge .Thus, the factors and indicators are utilized to develop as a model to measure the assumption of the research.

\section{Materials and Methods}

The researcher would like to develop and examine the accuracy of construct validity of the models used to measure self-discipline for good citizenship of the undergraduates, Chiang Mai University. The models include 4 main elements measured from 20 indicators and the combination of the indicators for each element is developed as a measurement model according to the specified assumption. It is expected that the findings will reveal the accordance between those models and empirical data

The data providers are the total of 1,407 undergraduates from 18 different faculties by the use of stratify random sampling when all faculties were defined as strata in the sampling method from the population of 25,152 persons. The sampled population was 585 male students (or $41.578 \%$ ) and 822 female students (or $58.422 \%$ ). The size of this sampled group used the estimation of 10 times to one assumption parameter model, so the number of 640 samples was required for 64 parameters in the hypothetical measurement model. It was found that the collected data was twice higher than the estimation .Additionally, the population was highly related to the number of samples (Pearson correlation coefficient $=0.743$ ).

The researcher developed the questionnaire to measure self-discipline, which is the rating scale of 5 levels, consisted of 89 items covering 4 main factors used for measuring structure of self-discipline, namely 1) responsibility consisting of 8 indicators (39 items), 2) honesty consisting of 2 indicators ( 8 items), 3 ) compliance consisting of 7 indicators (25 items) and 4) patience determination and intention containing 3 indicators (17 items). The results of discrimination of each item in each element calculated by item-total correlation $\left(\mathrm{r}_{\mathrm{xy}}\right)$ were $0.373-0.869,0.319-0.712,0.219-0.692$, and $0.394-$ 0.746 , respectively. The reliability (Cronbach's Alpha Coefficient: $\alpha$ ) for the measurement of each factor was $0.946,0.826,0.920$, and 0.901 , respectively. The total reliability was 0.963 . The students provided their data without time constraint when they were asked to consider each item and mark in small boxes for levels of ideas or practices which were matched to those of their points of view or factual details $(5=$ agree/practice the most, $1=$ agree/ practice the least). According to the data collection, it was revealed that the amount of time used in answering the questionnaires was 22-38 minutes and the rate of returning those questionnaires were $89.3 \%$ when the incomplete questionnaires were found at $1.608 \%$ and amount of time for collecting data was totally 2 weeks.

The researcher input all the data from the questionnaires to the computer and figure out the average of the data measuring the same indicator. Then, the distribution was examined by descriptive statistics and the relationship between the indicators was considered by the use of Pearson Product Moment Correlation Coefficient $\left(\mathrm{r}_{\mathrm{xy}}\right)$ as shown in the Table 2 and 3. The construct validity of assumption model was also examined by the method called Second-order Confirmatory Factor Analysis $\left(2^{\text {nd }}\right.$-order CFA) using the program Mplus 7.4 [24]. As for considering the validity, it was conducted by using a group of statistical values showing the correspondence between the empirical data and hypothetical model called "goodness of fit statistics", consisting of Relative Chi-square or the ratio between the Chi-square statistic $\left(\chi^{2}\right)$ and degree of freedom (df) which should not be higher than 2. The p-value at a level of 0.05 showed that there was no statistical significance .Moreover, Comparative Fit Index (CFI) and Tucker-Lewis Index (TLI) were also considered and they should be more than 0.90 (very good if higher than 0.95) whereas Standardized Root Mean Square Residual (SRMR (should be lower than 0.08 and the conformity was very good if Standardized Root (SRMR) was lower than 0.05 [25]. In addition, the parameters were also estimated by Maximum Likelihood method (ML) because the collected data was found in multivariate normal distribution [26].

\section{Results}

The findings from examining model validity show that the indicator value conforms to the empirical data which include $\chi={ }^{2} 187.931, \mathrm{df}=161, \chi{ }^{2} \mathrm{df}=1.167, \mathrm{p}$-value $=$ 0.072 , CFI $=0.998$, TLI $=0.998$, RMSEA $=0.001$, and $\mathrm{SRMR}=0.032$.According to the first order results, the measuring structure for self-discipline is combined with 4 main factors; 1) responsibility factor consisting of 8 
indicators and factor loading value of each indicator is different from zero with statistical significance of .01 when the outstanding indicators in this element are capability in accomplishing tasks or assignments $(\beta=0.714)$, punctuality $(\beta=0.707)$, and self-care $(\beta=0.693)$, respectively, 2) honesty factor consisting of 2 indicators and factor loading value of each indicator is different from zero with statistical significance of .01 when the outstanding indicator in this element is ability to accept the truth of the situation and its effects $(\beta=0.728), 3)$ compliance with regulations factor consisting of 7 indicators and factor loading value of each indicator is different from zero with statistical significance of .01 when the outstanding indicators in this element are the compliance with the university's rules, regulations and announcements $(\beta=0.909)$, respect for traffic regulations ( $\beta=0.816)$, and restraint from possession and carrying of lethal weapons ( $\beta=0.764)$, respectively, and 4) patience, determination, and intention factor containing 3 indicators and factor loading value of each indicator is different from zero with statistical significance of .01 when the outstanding indicator in this element is physical and emotional self-control $(\beta=0.877)$.

According to the second order factor loading coefficients of self-discipline as good citizenship, it shows that factor loading value of each indicator is different from zero with statistical significance of .01 when the element with the highest factor loading is patience, determination, and intention $(\beta=0.905)$, followed by responsibility ( $\beta=$ $0.901)$, honesty $(\beta=0.897)$, and compliance with regulations ( $\beta=0.694)$, respectively, as shown in Table 1 and Figure 1. Apart from this, latent variables in the five models are highly related in a positive way $\left(\mathrm{r}_{\mathrm{xy}}=0.622\right.$ 0.905) as shown in Table 2 and Table 3.

Table 1. Results of Confirmatory Factor Analysis on the second stage of self-discipline structure as good citizenship for the undergraduates

\begin{tabular}{|c|c|c|c|c|c|c|c|}
\hline Factors & Indicators & b & $\beta$ & S.E. & z-value & p-value & $\alpha$ \\
\hline \multicolumn{8}{|l|}{ First Order } \\
\hline \multirow{8}{*}{$\begin{array}{l}\text { (A) } \\
\text { Responsibility }\end{array}$} & A1: a success in tasks and assignments & 1.000 & 0.714 & 0.015 & 46.934 & 0.000 & 0.510 \\
\hline & A2: class attention & 1.004 & 0.691 & 0.015 & 45.823 & 0.000 & 0.478 \\
\hline & A3: preparation for study & 1.106 & 0.677 & 0.016 & 43.587 & 0.000 & 0.458 \\
\hline & $\begin{array}{l}\text { A4: participation in class and activities held by the } \\
\text { faculty and university }\end{array}$ & 1.048 & 0.687 & 0.014 & 47.862 & 0.000 & 0.472 \\
\hline & A5: punctuality & 1.116 & 0.707 & 0.015 & 46.872 & 0.000 & 0.500 \\
\hline & A6: protection of public properties & 1.023 & 0.672 & 0.015 & 43.782 & 0.000 & 0.452 \\
\hline & A7: follow-up of the faculty and university's information & 1.054 & 0.598 & 0.018 & 33.345 & 0.000 & 0.358 \\
\hline & A8: self-care & 0.903 & 0.693 & 0.015 & 44.747 & 0.000 & 0.481 \\
\hline \multirow{2}{*}{$\begin{array}{l}\text { (B) } \\
\text { Honesty }\end{array}$} & B1: acceptance of effects caused by one's own actions & 1.000 & 0.728 & 0.017 & 42.493 & 0.000 & 0.530 \\
\hline & B2: none of cheating & 0.893 & 0.691 & 0.016 & 42.740 & 0.000 & 0.478 \\
\hline \multirow{7}{*}{$\begin{array}{l}\text { (C) } \\
\text { Compliance } \\
\text { with regulations }\end{array}$} & $\mathrm{C} 1$ : respect for traffic rules & 1.000 & 0.816 & 0.015 & 55.667 & 0.000 & 0.666 \\
\hline & $\mathrm{C} 2$ : restraint from drinking alcohol and drug use & 0.809 & 0.632 & 0.014 & 45.448 & 0.000 & 0.399 \\
\hline & C3: restraint from physical and emotional abuse of others & 0.791 & 0.654 & 0.013 & 49.898 & 0.000 & 0.428 \\
\hline & C4: restraint from gambling & 0.755 & 0.529 & 0.018 & 29.264 & 0.000 & 0.280 \\
\hline & C5: restraint from offenses against property & 0.615 & 0.512 & 0.018 & 29.143 & 0.000 & 0.262 \\
\hline & $\begin{array}{l}\text { C6: compliance with university's regulations and } \\
\text { announcements }\end{array}$ & 0.787 & 0.909 & 0.009 & 104.737 & 0.000 & 0.826 \\
\hline & C7: no possession or carrying of lethal weapons & 0.784 & 0.764 & 0.012 & 61.909 & 0.000 & 0.583 \\
\hline \multirow{3}{*}{$\begin{array}{l}\text { (D) } \\
\text { Patience, } \\
\text { determination, } \\
\text { and intention }\end{array}$} & D1: attempt to accomplish the tasks and assignments & 1.000 & 0.748 & 0.013 & 55.632 & 0.000 & 0.559 \\
\hline & D2: physical and emotional self-control & 1.040 & 0.877 & 0.101 & 88.908 & 0.000 & 0.769 \\
\hline & D3: acquisition of knowledge & 1.109 & 0.672 & 0.017 & 40.515 & 0.000 & 0.452 \\
\hline \multicolumn{8}{|l|}{ Second Order } \\
\hline \multirow{4}{*}{$\begin{array}{l}\text { Self-discipline } \\
\text { for good } \\
\text { citizenship }\end{array}$} & (A) Responsibility & 1.000 & 0.901 & 0.011 & 82.945 & 0.000 & 0.881 \\
\hline & (B) Honesty & 1.119 & 0.897 & 0.015 & 61.345 & 0.000 & 0.804 \\
\hline & (C) Compliance with regulations & 1.123 & 0.694 & 0.014 & 49.179 & 0.000 & 0.481 \\
\hline & (D) Patience, determination, and intention & 1.076 & 0.905 & 0.011 & 78.989 & 0.000 & 0.820 \\
\hline
\end{tabular}




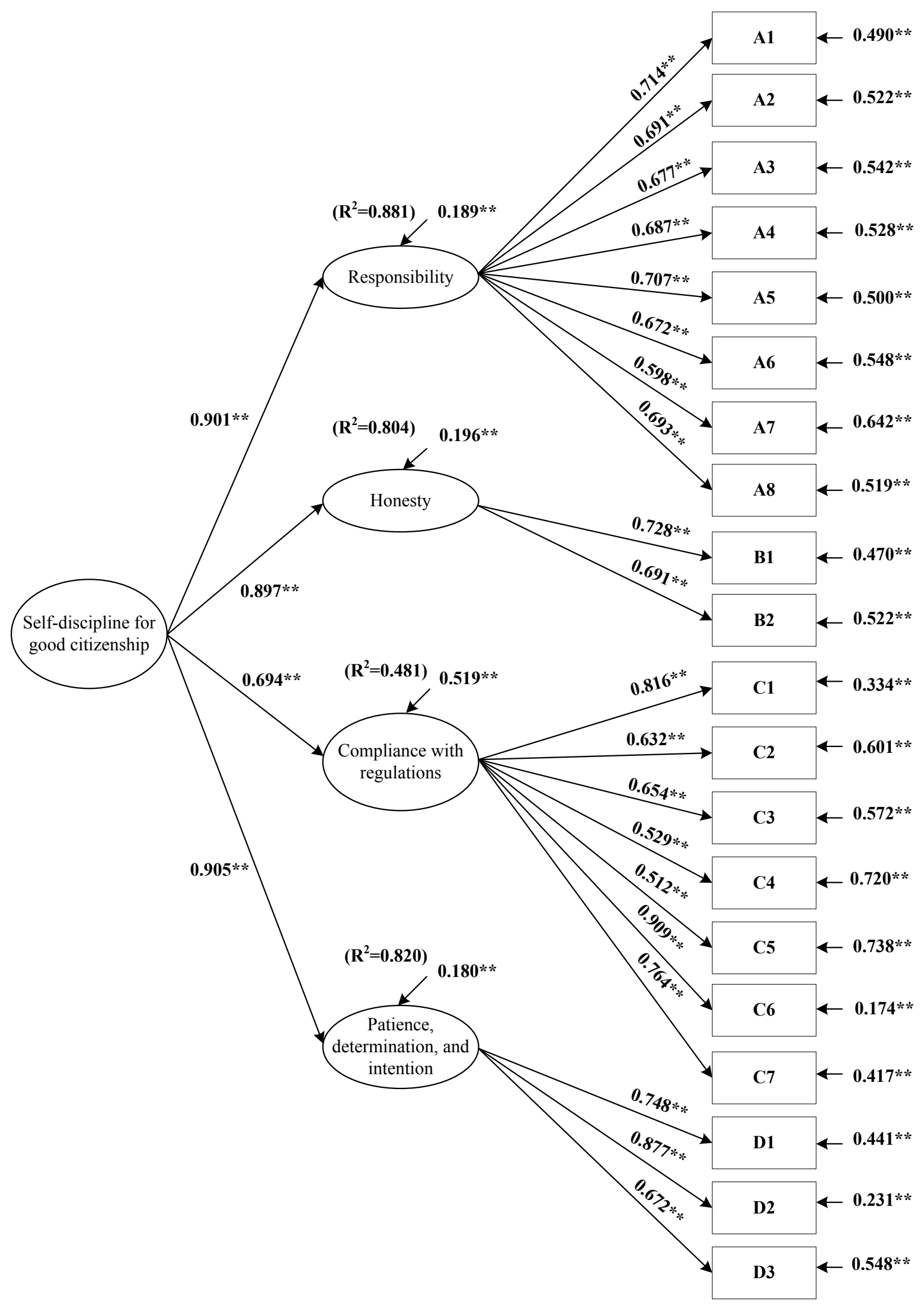

Remark: ** $\mathrm{p}<.01$

Figure 1. Model in measuring self-discipline as good citizenship for the undergraduates 
Table 2. Descriptive statistics and correlation coefficient metric of self-discipline indicators

\begin{tabular}{|c|c|c|c|c|c|c|c|c|c|c|c|c|c|c|c|c|c|c|c|c|c|}
\hline Factors & Indicators & A1 & A2 & A3 & A4 & A5 & A6 & A7 & A8 & B1 & B2 & C1 & C2 & C3 & $\mathrm{C} 4$ & C5 & C6 & C7 & D1 & D2 & D3 \\
\hline \multirow{8}{*}{$\begin{array}{l}\text { (A) } \\
\text { responsibility }\end{array}$} & A1 & 1.000 & & & & & & & & & & & & & & & & & & & \\
\hline & A2 & $\begin{array}{c}0.489 \\
* *\end{array}$ & 1.000 & & & & & & & & & & & & & & & & & & \\
\hline & A3 & $\begin{array}{c}0.499 \\
* *\end{array}$ & $\begin{array}{c}0.530 \\
* *\end{array}$ & 1.000 & & & & & & & & & & & & & & & & & \\
\hline & A4 & $\begin{array}{c}0.502 \\
* *\end{array}$ & $\begin{array}{c}.567 \\
* *\end{array}$ & $\begin{array}{c}0.560 \\
* *\end{array}$ & 1.000 & & & & & & & & & & & & & & & & \\
\hline & A5 & $\begin{array}{c}0.491 \\
* *\end{array}$ & $\begin{array}{c}0.426 \\
* *\end{array}$ & $\begin{array}{c}0.476 \\
* *\end{array}$ & $\begin{array}{c}0.487 \\
* * *\end{array}$ & 1.000 & & & & & & & & & & & & & & & \\
\hline & A6 & $\begin{array}{c}0.427 \\
* * \\
\end{array}$ & $\begin{array}{c}0.497 \\
* * \\
\end{array}$ & $\begin{array}{c}0.450 \\
* *\end{array}$ & $\begin{array}{c}0.600 \\
* * \\
\end{array}$ & $\begin{array}{c}0.465 \\
* *\end{array}$ & 1.000 & & & & & & & & & & & & & & \\
\hline & A7 & $\begin{array}{c}0.425 \\
* *\end{array}$ & $\begin{array}{c}0.416 \\
* *\end{array}$ & $\begin{array}{c}0.402 \\
* *\end{array}$ & $\begin{array}{c}0.504 \\
* *\end{array}$ & $\begin{array}{c}0.409 \\
* *\end{array}$ & $\begin{array}{c}0.556 \\
* * *\end{array}$ & 1.000 & & & & & & & & & & & & & \\
\hline & A8 & $\begin{array}{c}0.442 \\
* *\end{array}$ & $\begin{array}{c}0.511 \\
* *\end{array}$ & $\begin{array}{c}0.448 \\
* *\end{array}$ & $\begin{array}{c}0.472 \\
* *\end{array}$ & $\begin{array}{c}0.410 \\
* *\end{array}$ & $\begin{array}{c}0.486 \\
* *\end{array}$ & $\begin{array}{c}0.433 \\
* * *\end{array}$ & 1.000 & & & & & & & & & & & & \\
\hline \multirow{2}{*}{$\begin{array}{c}\text { (B) } \\
\text { honesty }\end{array}$} & B1 & $\begin{array}{c}0.413 \\
* *\end{array}$ & $\begin{array}{c}0.416 \\
* *\end{array}$ & $\begin{array}{c}0.376 \\
* *\end{array}$ & $\begin{array}{c}0.423 \\
* *\end{array}$ & $\begin{array}{c}0.411 \\
* *\end{array}$ & $\begin{array}{c}0.411 \\
* *\end{array}$ & $\begin{array}{c}0.366 \\
* *\end{array}$ & $\begin{array}{c}0.505 \\
* *\end{array}$ & 1.000 & & & & & & & & & & & \\
\hline & B2 & $\begin{array}{c}0.402 \\
* *\end{array}$ & $\begin{array}{c}0.326 \\
* *\end{array}$ & $\begin{array}{c}0.363 \\
* *\end{array}$ & $\begin{array}{c}0.349 \\
* * \\
\end{array}$ & $\begin{array}{c}0.482 \\
* *\end{array}$ & $\begin{array}{c}0.306 \\
* *\end{array}$ & $\begin{array}{c}0.324 \\
* *\end{array}$ & $\begin{array}{c}0.358 \\
* *\end{array}$ & $\begin{array}{c}0.527 \\
* *\end{array}$ & 1.000 & & & & & & & & & & \\
\hline \multirow{7}{*}{$\begin{array}{c}\text { (C) } \\
\text { compliance } \\
\text { with } \\
\text { regulations }\end{array}$} & $\mathrm{C} 1$ & $\begin{array}{c}0.339 \\
* *\end{array}$ & $\begin{array}{c}0.362 \\
* *\end{array}$ & $\begin{array}{c}0.350 \\
* *\end{array}$ & $\begin{array}{c}0.329 \\
* *\end{array}$ & $\begin{array}{c}0.402 \\
* *\end{array}$ & $\begin{array}{c}0.341 \\
* *\end{array}$ & $\begin{array}{c}0.314 \\
* *\end{array}$ & $\begin{array}{c}0.400 \\
* *\end{array}$ & $\begin{array}{c}0.387 \\
* *\end{array}$ & $\begin{array}{c}0.577 \\
* *\end{array}$ & 1.000 & & & & & & & & & \\
\hline & $\mathrm{C} 2$ & $\begin{array}{c}0.247 \\
* *\end{array}$ & $\begin{array}{c}0.184 \\
* *\end{array}$ & $\begin{array}{c}0.234 \\
* *\end{array}$ & $\begin{array}{c}0.186 \\
* *\end{array}$ & $\begin{array}{c}0.370 \\
* *\end{array}$ & $\begin{array}{c}0.143 \\
* *\end{array}$ & $\begin{array}{c}0.186 \\
* *\end{array}$ & $\begin{array}{c}0.195 \\
* *\end{array}$ & $\begin{array}{c}0.329 \\
* *\end{array}$ & $\begin{array}{c}0.617 \\
* *\end{array}$ & $\begin{array}{c}0.513 \\
* *\end{array}$ & 1.000 & & & & & & & & \\
\hline & C3 & $\begin{array}{c}0.273 \\
* *\end{array}$ & $\begin{array}{c}0.213 \\
* *\end{array}$ & $\begin{array}{c}0.236 \\
* *\end{array}$ & $\begin{array}{c}0.205 \\
* *\end{array}$ & $\begin{array}{c}0.390 \\
* *\end{array}$ & $\begin{array}{c}0.158 \\
* *\end{array}$ & $\begin{array}{c}0.194 \\
* *\end{array}$ & $\begin{array}{c}0.224 \\
* *\end{array}$ & $\begin{array}{c}0.352 \\
* *\end{array}$ & $\begin{array}{c}0.647 \\
* *\end{array}$ & $\begin{array}{c}0.514 \\
* *\end{array}$ & $\begin{array}{c}0.759 \\
* *\end{array}$ & 1.000 & & & & & & & \\
\hline & $\mathrm{C} 4$ & $\begin{array}{c}0.216 \\
* *\end{array}$ & $\begin{array}{c}0.259 \\
* *\end{array}$ & $\begin{array}{c}0.206 \\
* *\end{array}$ & $\begin{array}{c}0.170 \\
* *\end{array}$ & $\begin{array}{c}0.274 \\
* *\end{array}$ & $\begin{array}{c}0.157 \\
* *\end{array}$ & $\begin{array}{c}0.189 \\
* *\end{array}$ & $\begin{array}{c}0.220 \\
* *\end{array}$ & $\begin{array}{c}0.315 \\
* *\end{array}$ & $\begin{array}{c}0.488 \\
* *\end{array}$ & $\begin{array}{c}0.440 \\
* *\end{array}$ & $\begin{array}{c}0.515 \\
* *\end{array}$ & $\begin{array}{c}0.593 \\
* *\end{array}$ & 1.000 & & & & & & \\
\hline & C5 & $\begin{array}{c}0.220 \\
* *\end{array}$ & $\begin{array}{c}0.119 \\
* * \\
\end{array}$ & $\begin{array}{c}0.161 \\
* *\end{array}$ & $\begin{array}{c}0.140 \\
* * \\
\end{array}$ & $\begin{array}{c}0.373 \\
* *\end{array}$ & $\begin{array}{c}0.107 \\
* *\end{array}$ & $\begin{array}{c}0.167 \\
* *\end{array}$ & $\begin{array}{c}0.157 \\
* *\end{array}$ & $\begin{array}{c}0.321 \\
* *\end{array}$ & $\begin{array}{c}0.627 \\
* *\end{array}$ & $\begin{array}{c}0.461 \\
* *\end{array}$ & $\begin{array}{c}0.690 \\
* *\end{array}$ & $\begin{array}{c}0.742 \\
* *\end{array}$ & $\begin{array}{c}0.546 \\
* *\end{array}$ & 1.000 & & & & & \\
\hline & C6 & $\begin{array}{c}0.418 \\
* *\end{array}$ & $\begin{array}{c}0.317 \\
* *\end{array}$ & $\begin{array}{c}0.365 \\
* *\end{array}$ & $\begin{array}{c}0.338 \\
* *\end{array}$ & $\begin{array}{c}0.530 \\
* *\end{array}$ & $\begin{array}{c}0.333 \\
* *\end{array}$ & $\begin{array}{c}0.339 \\
* *\end{array}$ & $\begin{array}{c}0.385 \\
* *\end{array}$ & $\begin{array}{c}0.435 \\
* *\end{array}$ & $\begin{array}{c}0.607 \\
* *\end{array}$ & $\begin{array}{c}0.518 \\
* *\end{array}$ & $\begin{array}{c}0.579 \\
* *\end{array}$ & $\begin{array}{c}0.610 \\
* *\end{array}$ & $\begin{array}{c}0.476 \\
* *\end{array}$ & $\begin{array}{c}0.634 \\
* *\end{array}$ & 1.000 & & & & \\
\hline & C7 & $\begin{array}{c}0.314 \\
* *\end{array}$ & $\begin{array}{c}0.190 \\
* * \\
\end{array}$ & $\begin{array}{c}0.247 \\
* *\end{array}$ & $\begin{array}{c}0.209 \\
* * \\
\end{array}$ & $\begin{array}{c}0.438 \\
* *\end{array}$ & $\begin{array}{c}0.189 \\
* *\end{array}$ & $\begin{array}{c}0.234 \\
* *\end{array}$ & $\begin{array}{c}0.221 \\
* *\end{array}$ & $\begin{array}{c}0.335 \\
* *\end{array}$ & $\begin{array}{c}0.534 \\
* *\end{array}$ & $\begin{array}{c}0.431 \\
* *\end{array}$ & $\begin{array}{c}0.525 \\
* *\end{array}$ & $\begin{array}{c}0.557 \\
* *\end{array}$ & $\begin{array}{c}0.378 \\
* *\end{array}$ & $\begin{array}{c}0.595 \\
* *\end{array}$ & $\begin{array}{c}0.721 \\
* *\end{array}$ & 1.000 & & & \\
\hline \multirow{3}{*}{$\begin{array}{c}\text { (D) } \\
\text { patience, } \\
\text { determination } \\
\text {, and intention }\end{array}$} & D1 & $\begin{array}{c}0.489 \\
* *\end{array}$ & $\begin{array}{c}0.434 \\
* *\end{array}$ & $\begin{array}{c}0.499 \\
* *\end{array}$ & $\begin{array}{c}0.466 \\
* *\end{array}$ & $\begin{array}{c}0.433 \\
* *\end{array}$ & $\begin{array}{c}0.406 \\
* *\end{array}$ & $\begin{array}{c}0.387 \\
* *\end{array}$ & $\begin{array}{c}0.491 \\
* *\end{array}$ & $\begin{array}{c}0.423 \\
* *\end{array}$ & $\begin{array}{c}0.408 \\
* *\end{array}$ & $\begin{array}{c}0.390 \\
* *\end{array}$ & $\begin{array}{c}0.289 \\
* *\end{array}$ & $\begin{array}{c}0.315 \\
* *\end{array}$ & $\begin{array}{c}0.318 \\
* *\end{array}$ & $\begin{array}{c}0.272 \\
* *\end{array}$ & $\begin{array}{c}0.514 \\
* *\end{array}$ & $\begin{array}{c}0.424 \\
* *\end{array}$ & 1.000 & & \\
\hline & D2 & $\begin{array}{c}0.506 \\
* *\end{array}$ & $\begin{array}{c}0.485 \\
* *\end{array}$ & $\begin{array}{c}0.494 \\
* *\end{array}$ & $\begin{array}{c}0.477 \\
* * \\
\end{array}$ & $\begin{array}{c}0.497 \\
* *\end{array}$ & $\begin{array}{c}0.471 \\
* *\end{array}$ & $\begin{array}{c}0.419 \\
* *\end{array}$ & $\begin{array}{c}0.536 \\
* *\end{array}$ & $\begin{array}{c}0.512 \\
* *\end{array}$ & $\begin{array}{c}0.497 \\
* *\end{array}$ & $\begin{array}{c}0.453 \\
* *\end{array}$ & $\begin{array}{c}0.358 \\
* *\end{array}$ & $\begin{array}{c}0.426 \\
* *\end{array}$ & $\begin{array}{c}0.411 \\
* *\end{array}$ & $\begin{array}{c}0.385 \\
* *\end{array}$ & $\begin{array}{c}0.592 \\
* *\end{array}$ & $\begin{array}{c}0.469 \\
* *\end{array}$ & $\begin{array}{c}0.661 \\
* *\end{array}$ & 1.000 & \\
\hline & D3 & $\begin{array}{c}0.425 \\
* *\end{array}$ & $\begin{array}{c}0.303 \\
* * \\
\end{array}$ & $\begin{array}{c}0.392 \\
* *\end{array}$ & $\begin{array}{c}0.391 \\
* * \\
\end{array}$ & $\begin{array}{c}0.333 \\
* *\end{array}$ & $\begin{array}{c}0.404 \\
* *\end{array}$ & $\begin{array}{c}0.404 \\
* *\end{array}$ & $\begin{array}{c}0.379 \\
* *\end{array}$ & $\begin{array}{c}0.344 \\
* *\end{array}$ & $\begin{array}{c}0.348 \\
* *\end{array}$ & $\begin{array}{c}0.313 \\
* *\end{array}$ & $\begin{array}{c}0.216 \\
* *\end{array}$ & $\begin{array}{c}0.247 \\
* *\end{array}$ & $\begin{array}{c}0.204 \\
* *\end{array}$ & $\begin{array}{c}0.212 \\
* *\end{array}$ & $\begin{array}{c}0.390 \\
* *\end{array}$ & $\begin{array}{c}0.305 \\
* *\end{array}$ & $\begin{array}{c}0.500 \\
* *\end{array}$ & $\begin{array}{c}0.596 \\
* *\end{array}$ & 1.000 \\
\hline \multicolumn{2}{|c|}{ Mean } & 3.939 & 3.578 & 3.765 & 3.660 & 4.025 & 3.619 & 3.728 & 3.697 & 3.890 & 4.196 & 4.058 & 4.430 & 4.445 & 4.223 & 4.507 & 4.292 & 4.432 & 3.937 & 3.959 & 3.929 \\
\hline \multicolumn{2}{|c|}{ SD } & 0.578 & 0.600 & 0.676 & 0.632 & 0.651 & 0.632 & 0.730 & 0.540 & 0.637 & 0.603 & 0.736 & 0.775 & 0.733 & 0.864 & 0.741 & 0.525 & 0.627 & 0.592 & 0.525 & 0.730 \\
\hline
\end{tabular}

Note: 1$) \mathrm{KMO}=0.949$, Bartlett's Test $($ Chi-Square $=16224.553, \mathrm{df}=190, \mathrm{p}=0.000) ; 2) * * \mathrm{p}<.01$ 
Table 3. Correlation matrix for the latent variables (Factors)

\begin{tabular}{llllll}
\hline Latent Factor & (A) & (B) & (C) & (D) & (E) \\
(A) responsibility & 1.000 & & & & \\
(B) honesty & 0.808 & 1.000 & & & \\
(C) compliance with regulations & 0.625 & 0.622 & 1.000 & & \\
(D) patience, determination, and intention & 0.815 & 0.812 & 0.628 & 1.000 & \\
(E) self-discipline & 0.901 & 0.897 & 0.694 & 0.905 & 1.000 \\
\hline
\end{tabular}

\section{Discussion}

The findings show that there is a complexity in examining the qualities of self-discipline in the undergraduates, which has a wider scope than the understanding of general discipline. Four main factors can be used to greatly describe the structure of self-discipline as well as utilizing of all 20 indicators as a representative for perfectly measuring each element. The factor loading values of the elements are rather high and conform to the hypothesis, which the researcher expect that there are three main reasons to be discussed as follows.

First of all, synthesizing the elements and indicators from the relevant research, especially those in measuring self-discipline, allows the researcher to obtain the concept of indicators, which is used to specify a number of elements before developing into a hypothesis model, without conducting a new survey for both indicators and a number of elements. Furthermore, the definition and the design for the measurement of each indicator use the measuring question item no. 2 to 11 in an average of 4.45 items before examining the quality of a single question by a combination of recommendations from the experts in student development affairs, Chiang Mai University, and the trials for considering classification properties and analyzing the structure validity of the element. The purpose is to create indictors with quality to thoroughly measure the qualities of self-discipline and to make them suitable with the students who are familiar with learning environment and activities involving discipline in Chiang Mai University. When compared with the results from the research by Mahatmaharti et al [21], it reveals that there are differences in both elements and indicators. The element with a higher increase is honesty whereas others are likely to use a similar types and number of indicators. However, with a larger number of indicators and questions as well as a more concrete concept, it seems to the researcher that it is more obvious for all associates and anyone interested to be able to utilize or apply the study on behaviors of self-discipline in students from the stage of adolescence and that it is more useful and much clearer to make preparation of the youths as good citizens of the community.

Secondly, the test of measuring model and mature sampled group can completely use ethical reasoning and respond to social indicators better than students in a lower grade do [12] although it uses a longer list of measuring tools than the research, which examines general discipline. As it is previously concluded, self-discipline is one quality in the approach of ethical development, which explains the completeness of physical development. Eisenberg et al [17] describes 5 levels of prosocial development starting from providing others with assistance when obtaining the benefits (hedonistic level), which can be noticed from the pre-schooling age to grade 1-3 of the primary education, to the last level of providing others with assistance or cooperation due to personal reasoning towards social values and norms, beliefs, and responsibility (internal value orientation level), which can be found in upper secondary education as Piaget [19] explained that children at the stage of late adolescence are in the development level called concrete operational stage when they start to pay more attention to other individuals 'thoughts and needs. Subsequently, it is highly probable that, with all 20 indicators in the research framework containing definitions of technical terms covering highly abstract elements, there will be appropriate responses with concepts, practices, and beliefs which are personal qualities conforming to the stage of life.

Thirdly, the design of data collection from the sampled group according to techniques for data analysis reveals that the techniques for element analyzing play an important role in structural equation modeling (SEM) ([27]; [28]). The distinctive point is that the latent variable is utilized to separate the variation of true score out of the variation of measurement error before the true score is added up into the latent variable, which results in more measurement validity and reliability [24]. Nevertheless, this technique is based on the adequate size of sampled group in estimating the value of the parameter in such model of measurement [26]. In this research, data collected from the samples is adequate in both a number of parameters for value estimation and a number of the undergraduates as the population (when calculating from the formula, the population at the confidence level of $99 \%$ and confidence interval of 5\% reveal that 649 samples are needed).

Although the hypothesis testing model conforms to empirical information, there is one remarkable observation for the factor in compliance with regulation that contains 7 indicators but shows a lower factor loading than other factors containing similar factor loading. This matter leads the confidence in measuring the element to be less than 
twice as those of other elements. In contrast, the factor in honesty and the factor in patience and determination possess fewer indicators used in measuring but contain similar factor loading to that of the factor in responsibility with 8 indicators. This reveals that there may be some other indicators that are not included in the research framework and hypothesis testing model for measuring self-discipline in compliance with regulations.

According to the researcher's viewpoints regarding the findings from the study on indicators and measuring structure, all four main factors are necessary to be educated into children and youths, especially under the situation in Thailand where there are a lot of problems happening to the youths. This leads to conflicting opinions, family breakdown which used to be the foundation of nurturing and empowering children and youths with strong social immunity, consumption of social media without the use of critical thinking, neglect and non-involvement in correcting the wrong in society, and political participation without conscience and creativity. Therefore, not only are knowledge, special skills and specific expertise, ability to create an innovation developed to survive in an internationally competitive situation, educational institutions need to promote the youths to be responsible for caring for society and nation amidst the conflicting situation with the sense of belonging, peace, creativity, and compliance with regulations. The emphasis on the four main elements is the one important finding, which is different from those in other studies where the focus is on measuring and developing self-discipline in compliance with class regulations and self-responsibility.

The researcher would also like to support the top management, lecturers, and operational support personnel who are in charge of running projects supporting students to consider the elements and indicators from the research to develop the activities covering the structure of self-discipline for good citizenship in the undergraduates . The researcher believes that the personnel in each section are aware of encouraging self-discipline mainly in the compliance with university's regulations whereas there are several essential elements to be promoted as well .In case that it is unable to consider all indicators of each element, it is suggested that the most outstanding indicators be initially considered. For example, the most distinctive indicators from the element of responsibility are capability in accomplishing tasks or assignments (A1), punctuality (A5), and self-care (A2), which the behaviors related to these three indicators can also be observed in class.The element of compliance with regulations consists of three most outstanding indicators, which are the ability to follow the university's rules, regulations and announcements (C6), respect for traffic regulations $(\mathrm{C} 1)$, and restraint from possession or carrying of lethal weapons (C7), which can also be observed outside the class. Therefore, it is believed that the drive to develop self-discipline of the students is unable to be accomplished by only specific group, but it needs the cooperation from all sections to plan and operate continually and seriously in order to achieve the most inclusive and effective promotion of self-discipline. The study on causative factors affecting self-discipline for good citizenship in Chiang Mai University students should also be conducted because both internal and external surroundings of the campus are unique and different from other institutions [8]. It is expected that some causative factors, which can either promote or destroy self-discipline development of the students, may be particular, such as motivation, different social and cultural contexts, parenting or nurturing styles, difference in the course structure, qualities of fellows and lecturers, and media influences ([29]; [12]). These may lead to better understanding and ability to clearly describe the concept of developing activities and behaviors of the students.

\section{Acknowledgements}

The researcher would like to distribute the gratitude to the Division of Student Development, Chiang Mai University, for providing fund to this research. The researcher would also like to thank you all lecturers and students of the Program in Educational Evaluation and Research, the Faculty of Education, Chiang Mai University, for valuable technical comments and for assistance in data collecting, verifying, and recording under the time constraint until the research has been successfully completed.

\section{REFERENCES}

[1] G. G. Bear, J. F. Duquette. Fostering self-discipline. Principal Leadership, 9, 10-14, 2008.

[2] R. L. Curwin, A. N. Mendeler, Discipline with Dignity. Virginia: Edwards Brothers Inc, 1988.

[3] D. M. Pane, Viewing classroom discipline as negotiable social interaction: A communities of practice perspective. Teaching and Teacher Education, 26, 87-97, 2010.

[4] R. Lewis, S. Romi, X. Qui, Y .J. Katz. Teachers 'classroom discipline and student misbehavior in Australia, China and Israel. Teaching and Teacher Education, 21, 729-741, 2005.

[5] J. S. Pickering. Children with disabilities, Discipline : Developing self-control. Montessori Life, 15, 18-20, 2003.

[6] M. Pšunder. How effective is school discipline in preparing students to become responsible citizens? Slovenian teachers' and students' views. Teaching and Teacher Education, 21, 273-286, 2005.

[7] R. Rothstein. Towards a composite index of school performance. The Elementary School Teacher, 100, 409-441, 2000.

[8] S. Damrongpanit. Factors Affecting Self-discipline as Good Citizens for the Undergraduates of Chiang Mai 
University in Thailand: A Multilevel Path Analysis. Universal Journal of Educational Research, 7(21): 347-355, 2019.

[9] D. C. Orlich, R. J. Harder, R. C. Callahan, M. S. Trevisan, A. H. Brown, D. E. Miller. Teaching Strategies, a guide to effective instruction $\left(10^{\text {th }}\right.$ ed.). Wadsworth; CA, USA, 2013.

[10] C. M. Evertson, E. T. Emmer. Effective management at the beginning of the school year in journal high classes. Journal of Educational Psychology, 24, 485-498, 1982.

[11] W. W. Wayson. Opening windows to teaching :Empowering educators to teach self-discipline. Theory into Practices, 24, 227-232, 1985 .

[12] D. R. Shaffer. Social and Personality Development $\left(6^{\text {th }}\right.$ ed.). CA: Wadsworth, 2009.

[13] C. T. Ugurlu, K. Beycioglu, Y. Kondakci, M. Sincar, M. C. Yildirm, N. Ozer, A. Oncel. The Views of Teachers towards Perception of Discipline in Schools. Procedia - Social and Behavioral Sciences, 197, 120-125, 2015.

[14] K. Alotaibi. The learning environment as a mediating variable between self-directed learning readiness and academic performance of a sample of Saudi nursing and medical emergency students. Nurse Education Today, 36, 249-254, 2016.

[15] Y. Gong, D. Rai, J. E. Beck, N. T. Hefferman. Dose self-discipline impact students' knowledge and learning? Educational Data Mining, 61-70, 2009.

[16] A. Lohbeck, J. Schulteiß, U. Petermann, F. Petermann. Factor structure and measurement invariance of the studenrs' self-report checklist of social and learning behavior (SSL). Learning and Individual Differences, 51, 314-321, 2016.

[17] N. Eisenberg, R. Lennon, K. Roth. Prosocial development :A longitudinal study. Development Psychology, 19, 846-855, 1983.

[18] A. Bandura. Social Cognitive Theory .In R .Vasta )Ed(., Connecticut: JAI Press, 1989.

[19] J. Piaget. Piaget's theory .In P .H .Mussen (Ed.). Carmichael's Manual of Child Psychology. New York: Wiley, 1970.

[20] L. Kohlberg. The development of children's orientations toward a model order: I. Sequence in the development of moral thought. Vita Humana, 6, 11-33, 1963.

[21] A. K. Mahatmahart, W. Ardhana, Triyono, F. Hanurawan. Construct validity in research development instruments :The analysis of self-discipline factors. Journal of Humanities and Social Science, 22, 33-40, 2017.

[22] B. J. Zimmerman. Attainment of self-regulation: A social cognitive perspective. In M. Boekaerts, P. R. Pintrich, \& M. Zeidner (Eds.), Handbook of self-regulation. CA: Academic Press, 2000.

[23] M. S. Gilliom, D. S. Beck, J. A. Schonberg, A. Michael, E. L. Lukon. Anger Regulation in disadvantaged preschool boys : Strategies, antecedents and the development of self-control. Development Psychology, 38, 222-235, 2002.

[24] B .M. Byrne. Structural Equation Modeling with Mplus :Basic Concepts, Applications, and Programming. New York: Routledge, 2012.
[25] R. E. Schumacker, R. G. Lomax. A Beginner's Guide to Structural Equation Modeling ( ${ }^{\text {rd }}$ ed.). New York: Routledge, 2010.

[26] E. K. Kelloway. Using Mplus for Structural Equation Modeling :A Researcher's Guide ( $2^{\text {nd }}$ ed.). CA: Sage, 2015.

[27] C. Geiser. Data Analysis with Mplus. New York: Guilford Press, 2010.

[28] R. B. Kline. Principles and Practice of Structural Equation Modeling ( $2^{\text {nd }}$ ed.). New York: Guilford Press, 2005.

[29] C. H. Wolfgang. Solving discipline problems: methods and models for today's teachers ( $4^{\text {th }}$ ed.). Boston: Allyn and Bacon, 1999. 